\title{
UJI AKTIVITAS ANTI-AGING SEDIAAN BLEMISH BALM CREAM VITAMIN E KOMBINASI AVOBENZONE DAN OKTIL METOKSISINAMAT
}

\author{
Citra Sari Dewi Siregar ${ }^{*}$, Taufiq Qurrahman ${ }^{2}$, Yuni Andriani Nasution ${ }^{3}$ \\ 1,2,3Program Studi Farmasi, Sekolah Tinggi Ilmu Kesehatan Namira Madina, Panyabungan, \\ Indonesia \\ Email: citra.saridewi52@gmail.com \\ *corresponding author
}

\begin{abstract}
Abstrak
Radiasi elektromagnetik di bawah sinar matahari disebut ultraviolet (UV) yang telah dikenal sebagai faktor utama penyebab kerusakan kulit. Paparan sinar matahari yang berlebih akan mempercepat terjadinya proses photoaging sehingga menyebabkan kelainan pada kulit seperti kulit kemerahan, terbentuknya kerutan, kerusakan jaringan dermis, penurunan elastisitas kulit, penurunan kolagen dan penuaan dini. Sediaan Blemish Balm Cream termasuk kosmetik antiaging yang dapat dipakai sebagai kosmetik dekoratif yang mampu menghindari efek buruk pada kulit dan dapat dipakai untuk semua jenis kulit. Blemish Balm Cream salah kosmetik wajah yang dirancang dari formula face powder dan foundation cream dengan kandungan Vitamin, UVA dan UVB. Penelitian ini bertujuan untuk membuat formulasi Blemish Balm Cream dengan variasi konsentrasi vitamin E kombinasi avobenzone, oktil metoksisinamat dan uji pengaruh aktivitas anti-aging. Formulasi Blemish Balm Cream dilakukan dengan metode pencampuran dan metode peleburuan, dimana hasil formula face powder dan formula foundation cream diformulasikan dalam sediaan cream hingga terbentuk menjadi sediaan Blemish Balm Cream. Tiap formula mengandung vitamin E 0\%,1\%,3\%, 5\%, avobenzone 3\% dan oktil metoksisinamat 7,5\%. Formula sediaan Blemish Balm Cream yang terbentuk dilakukan tahap evaluasi aktivitas anti-aging dengan menggunakan skin analyzer. Hasil penelitian menunjukkan bahwa Formulasi Blemish Balm Cream dengan kandungan vitamin E yang dikombinasi avobenzone dan oktilmetoksisinamat stabil pada suhu kamar, sediaan yang dihasilkan bersifat homogen berwarna kuning kecoklatan, memiliki tipe emulsi bersifat $\mathrm{m} / \mathrm{a}$, stabil pada suhu rendah, suhu tinggi dan suhu ruangan, memiliki $\mathrm{pH}$ 6,6-7,0 dan stabil dalam uji cyling test. Blemish Balm Cream yang mengandung vitamin E konsentrasi 5\% memberikan efek aktivitas anti-aging yang lebih cepat dibandingkan sediaan tanpa kandungan vitamin E. Vitamin E kombinasi avobenzone dan oktil metoksisinamat dapat diformulasikan menjadi sediaan Blemish Balm Cream dan stabil dalam penyimpanan suhu kamar sehingga mampu memberikan efek aktivitas anti-aging yang baik, tidak mengiritasi kulit sukarealwan dan memberikan perubahan kulit wajah sukarelawan yang ditandai dengan meningkatnya kelembaban kulit, pengecilan pori, pengurangan jumlah noda dan pengurangan keriput.
\end{abstract}

Kata kunci: Blemish Balm Cream; Anti-aging; Vitamin E; Avobenzone; Oktil metoksisinamat 


\begin{abstract}
The exposures of UV rays on the skin can lead to the formation of free radicals and accelerate the aging process of the skin. The exposure of UV could make redness skin, formation of wrinkles, damage to dermis tissue and premature aging. Blemish Balm Cream (BBC) is one of the antiaging cosmetics and decorative cosmetics suitable for use to avoid adverse effects on the skin and can be used for all skin types. Blemish Balm Cream (BBC) is a facial cosmetic preparation consisting of Face Powder and Foundation Cream formulas in the form of creams containing Vitamins, UVA and UVB. This study aims to create a formulation of Blemish Balm Cream with variations in the concentration of vitamin $E$ and determination avobenzone and octyl methoxycinamate the evaluation of anti-aging activities. Blemish Balm Cream was made by mixing method wich the results of the face powder formula and foundation cream formula were made in the form of a cream to form a Blemish Balm Cream preparation. Each formula contains vitamin E 0\%, 1\%, 3\%, 5\% combination avobenzone 3\% sunscreen, and octyl methoxycinamate 7,5\%. Blemish Balm Cream that was preparation the activity evaluation anti-aging using a skin analyzer. The results showed that the Blemish Balm Cream formulation containing vitamin $E$ combined with avobenzone and octylmethoxycinnamate was stable at room temperature, the resulting preparation was homogeneous in brownish yellow color, had an o/w type emulsion, was stable at low temperature, high temperature and room temperature. has a pH of 6.6-7.0 and is stable in the cyling test. Blemish Balm Cream containing $5 \%$ concentration of vitamin E provides a faster anti-aging activity effect than preparations without vitamin E. Vitamin E combination of avobenzone and octyl methoxycinnamate can be formulated into Blemish Balm Cream preparations and is stable in room temperature storage so that it can give effect good anti-aging activity, does not irritate the skin of volunteers and provides changes to the volunteer's facial skin which is characterized by increased skin moisture, pore reduction, reduced number of blemishes and reduction of wrinkles.
\end{abstract}

Keywords: Blemish Balm Cream, Anti-aging, Formulation, Vitamin E, Avobenzone, Octyl methoxycinnamate

\title{
PENDAHULUAN
}

Radiasi elektromagnetik di bawah sinar matahari disebut ultraviolet (UV) yang telah dikenal sebagai faktor utama penyebab kerusakan kulit. Paparan sinar UV dapat mempercepat proses penuaan kulit yang mampu menjadikan perubahan pada kulit seperti kulit kemerahan, terbentuknya kerutan pada kulit, penuaan dini, peningkatan mediator inflamasi, penurunan elastisitas kulit dan penurunan sintesis kolagen (Arakane et.al., 2016).

Salah satu sediaan kosmetik wajah yang dapat dijadikan sebagai alternatif menghindari kulit dari pengaruh sinar matahari adalah Blemish Balm Cream (Baldechi et.al., 2012). Blemish Balm Cream termasuk kosmetik wajah multifungsi yang dapat dijadikan sebagai kosmetik dekoratif dan kosmetik perawatan wajah yang lebih ringan dan praktis, sehingga tidak akan terasa berat di wajah saat dipakai. Blemish Balm Cream cocok untuk semua jenis kulit, baik kulit berminyak maupun kulit kering, dapat dipakai sesuai kebutuhan kulit wajah dan dapat dipakai pada remaja, dewasa dan lanjut usia, sehingga Blemish Balm Cream dianggap produk kosmetik wajah yang cukup lengkap dan efisien (Baldechi et.al., 2012).

Anti-aging adalah suatu proses pencegahan kerusakan kulit terutama pada wajah dengan munculnya perubahan yang terlihat pada kulit seperti kulit kemerahan, 
terbentuknya kerutan pada kulit, peningkatan mediator inflamasi, kelembaban kulit berkurang, menurunnya elastisitas kulit, tekstur kulit menjadi kasar, hiperpigmentasi, penurunan sintesis kolagen dan kulit berwarna gelap (Reveny, J., 2017).

Vitamin yang dapat menangkal radikal bebas adalah vitamin E. Vitamin E termasuk golongan antioksidan yang dapat melawan radikal bebas sehingga mampu memperlambat proses penuaan, menutrisi kulit, menghaluskan kulit, mencerahkan hiperpigmentasi, merangsang sintesis kolagen, antiinflamasi, sebagai agen fotoprotektif dan mengurangi kondisi kulit yang kering sehingga dapat membantu meningkatkan aktivitas sediaan kosmetik. Konsentrasi vitamin E yang umum digunakan pada sediaan topikal adalah 1-5\% (Mukul et.al., 2011).

Untuk mengoptimalkan paparan tabir surya ke kulit dilakukan penambahan kombinasi bahan tabir surya bersifat kimia dan tabir surya bersifat fisika sehingga mampu meningkatkan aktivitas perlindungan terhadap radiasi UV (Afonso et.al., 2014).

Avobenzon merupakan bahan kimia penangkal UVA dan oktil metoksisinamat merupakan penangkal UVB, sehingga pada penelitian ini avobenzon $3 \%$ dan oktil metoksisinamat $7,5 \%$ digunakan sebagai bahan tabir surya. Konsentrasi avobenzon yang umum digunakan adalah 3\% dan konsentrasi oktil metoksisinamat adalah 7,5\% (Rosita et.al., 2010). Kombinasi kedua bahan ini dapat meningkatkan stabilitas dari sediaan dan dapat meningkatkan nilai Sun Protectotion Factor (Baki et.al., 2015).

Berdasarkan uraian latar belakang di atas maka peneliti bertujuan untuk melakukan evaluasi aktivitas anti-aging sediaan Blemish Balm Cream yang mengandung vitamin $\mathrm{E}$ dengan variasi konsentrasi $\mathrm{F} 1 ; 1 \%, \mathrm{~F} 2 ; 3 \%$ dan $\mathrm{F} 3 ; 5 \%$ dengan kombinasi bahan tabir surya avobenzon 3\% dan oktil metoksisinamat 7,5\%. Aktivitas anti-aging sediaan Blemish Balm Cream dievaluasi dengan menggunakan alat skin analyzer.

\section{METODE PENELITIAN}

Metode yang digunakan pada penelitian ini menggunakan metode eksperimental, meliputi pembuatan formulasi Blemish Balm Cream anti-aging dengan kandungan vitamin $\mathrm{E}$ dan kombinasi bahan tabir surya avobenzon 3\% dan oktil metoksisinamat 7,5\%. Sediaan Blemish Balm Cream yang terbentuk dilakukan uji evaluasi aktivitas antiaging dengan menggunakan alat skin analyzer.

Penelitian ini dilakukan Februari-Juni 2021 di Laboratorium Kosmetologi Fakultas Farmasi, Laboratorium Penelitian Fakultas Farmasi Universitas Sumatera Utara Medan dan Laboratorium STIKes Namira Madina Panyabungan. Alat yang digunakan pada penelitian ini adalah neraca analitik (Ohrus), magnetic stirrer (BOECO Germany), sonikator (Branson), Skin analyzer (Aramo), penangas air, oven (Memmert), spatula dan sudip, pot plastik, Cawan petri, objek gelas, lumpang dan stamper, dan alat-alat gelas laboratorium. Bahan-bahan yang digunakan dalam penelitian ini adalah avobenzon (Vivimed), oktil metoksisinamat (BTC), vitamin E (Zhejuang), talkum (Galenova), kaolin (Takehara Kagaku Kogyo), calcium carbonate (CSPC), zinc oxide (Phar Grade), zinc stearat (CSPC), magnesium carbonate, yellow iron oxide (BTC), parfume, cetil alkohol, asam stearat (Petronas), aquades, glyserin, dan nipagin.

Tahap pembuatan formulasi yang dilakukan pada penelitian adalah menggunakan variasi konsentrasi vitamin $\mathrm{E}$ dan bahan tabir surya avobenzon, dan oktil metoksisinamat yang mengacu pada formula standar menurut Kumar (2018) dan penelitian sebelumnya menggunakan vitamin E konsentrasi 1-5\% (Mukul et.al., 2011). 
Tabel 1. Formula Blemish Balm Cream modifikasi

\begin{tabular}{lcccc}
\hline \multicolumn{1}{c}{ Bahan } & F0 $(\boldsymbol{\%} \mathbf{b} / \mathbf{b})$ & $\mathbf{F 1}(\boldsymbol{\%} \mathbf{b} / \mathbf{b})$ & $\mathbf{F 2}(\boldsymbol{\%} \mathbf{b} / \mathbf{b})$ & $\mathbf{F 3}(\mathbf{\%} \mathbf{b} / \mathbf{b})$ \\
\hline Vitamin E & 0 & 1 & 3 & 5 \\
Avobenzon & 3 & 3 & 3 & 3 \\
Oktilmetoksisinamat & 7,5 & 7,5 & 7,5 & 7,5 \\
\hline Blemish Balm Cream ad & $\mathbf{1 0 0}$ & $\mathbf{1 0 0}$ & $\mathbf{1 0 0}$ & $\mathbf{1 0 0}$ \\
\hline
\end{tabular}

\section{Keterangan:}

F0: Blemish Balm Cream tanpa vitamin E

F1: Blemish Balm Cream konsentrasi vitamin E 1\%

F2: Blemish Balm Cream konsentrasi vitamin E 3\%

F3: Blemish Balm Cream konsentrasi vitamin E 5\%

Evaluasi fisik sediaan meliputi organoleptis, homogenitas, $\mathrm{pH}$, penentuan tipe emulsi,viskositas sediaan, cycling test, daya sebar, uji stabilitas sediaan dan evaluasi aktivitas anti-aging meliputi kadar air, kehalusan, noda, pori dan keriput. Evaluasi aktivitas anti-aging Blemish Balm Cream dilakukan terhadap sukarelawan wanita berusia 20-35 tahun sebanyak 24 orang dengan 4 kelompok.

Sukarelawan diukur kondisi kulit wajahnya dari kondisi awal meliputi kadar air (moisture), pori (pore), noda (melanin) dan kerutan (wrinkle) menggunakan alat skin analyzer. Perawatan dilakukan dengan mengaplikasikan sediaan Blemish Balm Cream pada wajah dua kali sehari pagi dan siang hari. Kondisi kulit dilihat saat sebelum dan setelah memakai sediaan Blemish Balm Cream selama empat minggu dengan menggunakan alat Skin Analyzer.

Data hasil pengukuran aktivitas anti-aging dengan skin analyzer dianalisis dengan menggunakan program Statistical Product and Service Solution (SPSS). Data yang diperoleh dianalisis menggunakan Kolmogorov-Smirnov Test. Selanjutnya data diolah dengan metode Two Way Anova untuk menganalisis pengaruh formula terhadap kondisi kulit selama pemakaian sediaan dalam waktu selama empat minggu perawatan.

\section{HASIL DAN PEMBAHASAN}

Pada penelitian ini, sediaan Blemish Balm Cream dibuat dengan menggunakam formula yang telah dimodifikasi dari formula face powder dan formula foundation cream yang mengacu pada formula Kumar (2018). Sediaan Blemish Balm Cream yang dibuat mengandung vitamin $\mathrm{E}$ dan bahan tabir surya. Vitamin $\mathrm{E}$ termasuk antioksidan yang digunakan sebagai pelembab dalam pembuatan sediaan dermatologi khususnya produk kosmetik wajah dan kulit (IOM, 2000). Penambahan vitamin E pada Blemish Balm Cream berfungsi sebagai emolient pada sediaan sehingga bermanfaat untuk anti-aging kulit dan antioksidan yang mampu menangkal radikal bebas dan menghindari kekeringan kulit.

Pada tiap formula konsentrasi vitamin E yang digunakan 1\%, 3\%, dan 5\%, sedangkan konsentrasi bahan tabir surya pada masing-masing formula avobenzon 3\% dan oktil metoksisinamat 7,5\%. Hasil formulasi Blemish Balm Cream Vitamin E dengan konsentrasi 1\%, 3\% dan 5\% menghasilkan sediaan yang berwarna kuning kecoklatan dan berbau khas rose. 
Tabel 2. Hasil Evaluasi Fisik Sediaan Blemish Balm Cream

\begin{tabular}{|c|c|}
\hline Jenis Uji & Hasil \\
\hline \multicolumn{2}{|l|}{ Organoleptis: } \\
\hline Warna & Kuning kecoklatan \\
\hline $\mathrm{Bau}$ & Khas rose \\
\hline Bentuk & Krim \\
\hline Homogenitas & Tidak ditemukan adanya butiran kasar pada tiap formula \\
\hline $\begin{array}{l}\text { Stabilitas pada Suhu kamar } \\
\left(27 \pm 2^{\circ} \mathrm{C}\right)\end{array}$ & Stabil, tidak terjadi perubahan warna, bau dan bentuk. \\
\hline
\end{tabular}

\section{Keterangan:}

F0: Blemish Balm Cream tanpa vitamin E

F1: Blemish Balm Cream konsentrasi vitamin E 1\%

F2: Blemish Balm Cream konsentrasi vitamin E 3\%

F3: Blemish Balm Cream konsentrasi vitamin E 5\%

$\mathrm{H}$ : Homogen, KC: Kuning kecokelatan, KH: Khas

Berdasarkan data uji $\mathrm{pH}$ yang diperoleh dan dapat dilihat dari masing-masing tabel dan grafik bahwa pH Blemish Balm Cream selama penyimpanan pada suhu kamar sediaan tetap stabil. Konsentrasi yang mengandung vitamin E yang berbeda-beda mengalami sedikit penurunan $\mathrm{pH}$ setelah penyimpanan selama 12 minggu, $\mathrm{pH}$ sediaan pada F0, F1, F2 dan F3 masih memenuhi rentang $\mathrm{pH}$ kulit yang sesuai dengan syarat $\mathrm{pH}$ normal kulit yaitu antara 4,5-7,0. Nilai pH kulit berdasarkan SNI 16-4399-1996 syarat mutu $\mathrm{pH}$ sediaan tabir surya yaitu 4,5-8 sehingga sediaan yang dibuat masih aman digunakan dan tidak menyebabkan iritasi pada kulit (Wasitaatmadja, 1997).

\section{Hasil pengukuran pH Blemish Balm Cream anti-aging selama 12 minggu}

Tabel 3. Hasil pengukuran pH Blemish Balm Cream anti-aging selama 12 minggu

\begin{tabular}{ccccc}
\hline \multirow{2}{*}{ Waktu (Minggu) } & \multicolumn{5}{c}{ pH } \\
\cline { 2 - 5 } & F0 & F1 & F2 & F3 \\
\hline 0 & $7,1 \pm 0,05$ & $7,5 \pm 0,1$ & $7,6 \pm 0,05$ & $7,0 \pm 0,06$ \\
\hline 1 & $7,0 \pm 0,05$ & $6,8 \pm 0,1$ & $7,0 \pm 0,05$ & $7,0 \pm 0,05$ \\
\hline 2 & $7,0 \pm 0,05$ & $6,8 \pm 0,05$ & $7,0 \pm 0,06$ & $7,0 \pm 0,05$ \\
\hline 3 & $7,0 \pm 0,05$ & $6,7 \pm 0,05$ & $7,0 \pm 0,05$ & $7,0 \pm 0,05$ \\
\hline 4 & $6,6 \pm 0,05$ & $6,7 \pm 0,05$ & $6,8 \pm 0,00$ & $6,8 \pm 0,00$ \\
\hline 5 & $6,7 \pm 0,06$ & $6,6 \pm 0,00$ & $6,8 \pm 0,00$ & $6,7 \pm 0,00$ \\
\hline 6 & $6,6 \pm 0,00$ & $6,5 \pm 0,05$ & $6,8 \pm 0,1$ & $6,7 \pm 0,1$ \\
\hline 7 & $6,2 \pm 0,05$ & $6,4 \pm 0,05$ & $6,7 \pm 0,1$ & $6,7 \pm 0,00$ \\
\hline 8 & $7,0 \pm 0,05$ & $6,4 \pm 0,00$ & $6,5 \pm 0,05$ & $6,7 \pm 0,00$ \\
\hline 9 & $6,2 \pm 0,05$ & $6,4 \pm 0,05$ & $6,4 \pm 0,00$ & $6,4 \pm 0,05$ \\
\hline 10 & $6,2 \pm 0,06$ & $6,3 \pm 0,00$ & $6,3 \pm 0,00$ & $6,4 \pm 0,05$ \\
\hline 11 & $6,0 \pm 0,00$ & $6,3 \pm 0,00$ & $6,3 \pm 0,00$ & $6,3 \pm 0,05$ \\
\hline 12 & $6,0 \pm 0,00$ & $6,0 \pm 0,05$ & $6,3 \pm 0,05$ & $6,3 \pm 0,05$ \\
\hline
\end{tabular}

\section{Keterangan:}

F0: Blemish Balm Cream tanpa vitamin E

F1: Blemish Balm Cream konsentrasi vitamin E 1\%

F2: Blemish Balm Cream konsentrasi vtamin E 3\%

F3: Blemish Balm Cream konsentrasi vitamin E 5\% 


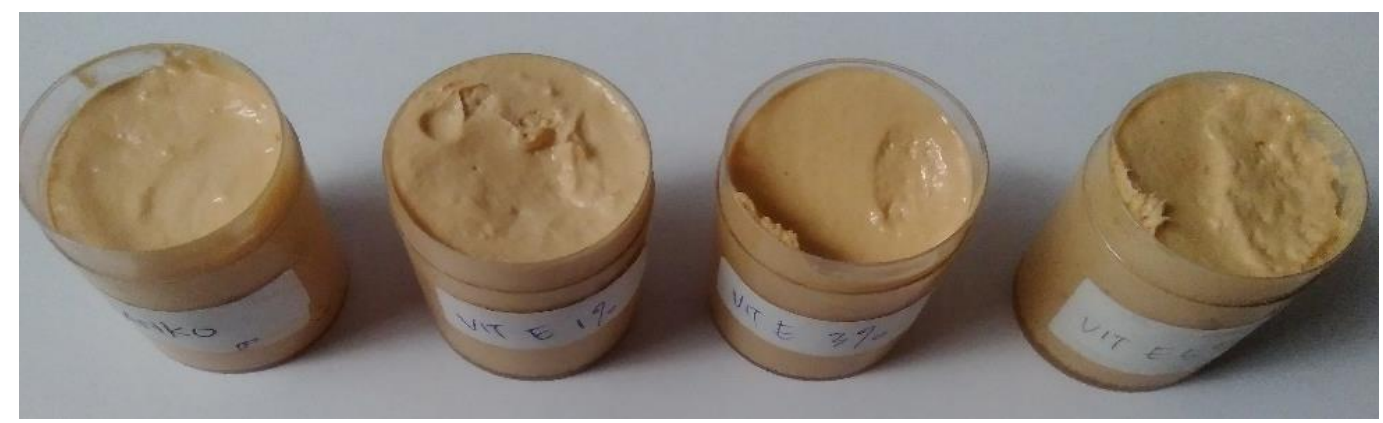

Gambar 1. Hasil Sediaan Blemish Balm Cream setelah penyimpanan suhu kamar

\section{Keterangan:}

F0: Blemish Balm Cream tanpa vitamin E

F1: Blemish Balm Cream konsentrasi vitamin E $1 \%$

F2: Blemish Balm Cream konsentrasi vtamin E 3\%

F3: Blemish Balm Cream konsentrasi vitamin E 5\%

Berdasarkan hasil uji stabilitas Blemish Balm Cream pada penyimpanan suhu kamar menunjukkan bahwa sediaan Blemish Balm Cream dari setiap formula tidak mengalami perubahan bentuk, warna, dan bau dari awal penyimpanan sampai minggu ke12. Hal ini menunjukkan bahwa sediaan Blemish Balm Cream pada F0, F1, F2 dan F3 stabil secara fisik pada suhu kamar.

\section{Hasil Pengukuran Kadar Air (Moisture)}

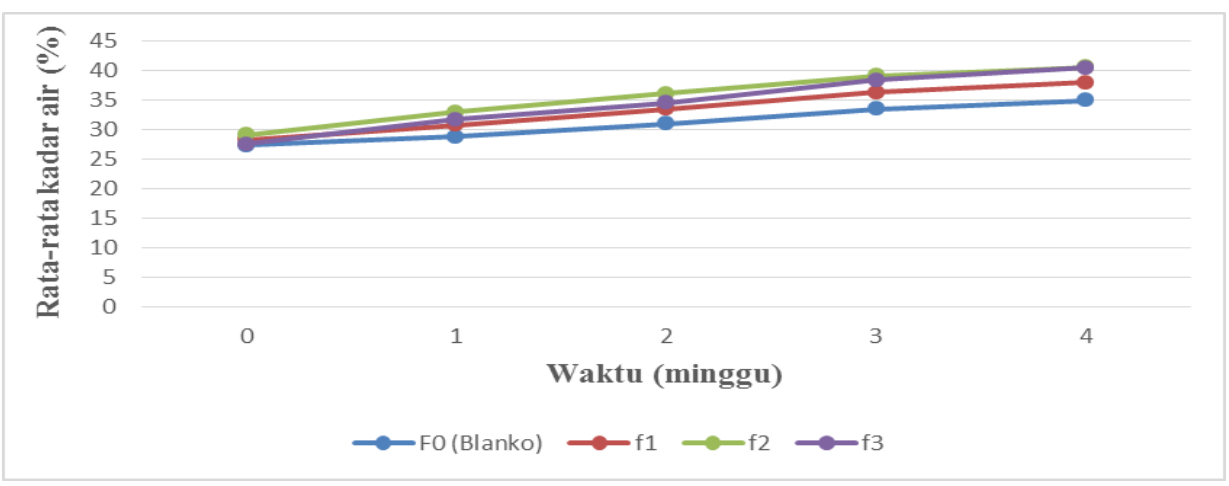

Gambar 2. Grafik hasil pengukuran kadar air (moisture) selama 4 minggu

\section{Keterangan:}

Normal : 30-44; Dehidrasi:0-29; Hidrasi: 45-100

F0: Blemish Balm Cream tanpa vitamin E

F1: Blemish Balm Cream konsentrasi vitamin E 1\%

F2: Blemish Balm Cream konsentrasi vtamin E 3\%

F3: Blemish Balm Cream konsentrasi vitamin E 5\% 
Berdasarkan hasil pengukuran kadar air yang diperoleh dapat dilihat bahwa sebelum pemakaian Blemish Balm Cream anti-aging hampir semua wajah sukarelawan mengalami kulit kering (dehidrasi), setelah pemakaian Blemish Balm Cream anti-aging terjadi peningkatan persen kadar air secara bertahap yang menjadikan kulit sukarelawan menjadi normal.

Hasil analisis statistik Kolmogorov-Smirnov Test dari pengukuran kadar air menunjukkan adanya perbedaan yang signifikan $(\mathrm{p} \leq 0,05)$ pada $\mathrm{F} 0, \mathrm{~F} 1, \mathrm{~F} 2$ dan F3 setelah pemakaian sediaan Blemish Balm Cream selama 4 minggu yang menunjukkan bahwa terdapat perbedaan peningkatan kadar air dan pengaruh kondisi kulit yang signifikan antara Blemish Balm Cream tanpa vitamin E (blanko) dengan formula yang mengandung vitamin E (F1, F2 Dan F3) aktivitas vitamin E mudah berpenetrasi melewati lapisan kulit dan meningkatkan kadar air dalam kulit menjadi lebih efektif.

Sediaan Blemish Balm Cream tanpa mengandung vitamin E (blanko) memiliki persentase peningkatan kadar air yang lebih lama dibandingkan F1, F2 dan F3, dimana hasil rata-rata persentasi kadar air yang diperoleh sebelum pemakaian hingga setelah pemakaian 4 minggu adalah F0: 27,33-35\%., F1: 28,33-38\%., F2: 29,16-40,66\% dan F3:27,6-40,5\% . Batas persentase Kadar air normal pada kulit wajah adalah 30-44\% (Aramo, 2012).

Menurut Loden dan Maibach (2006), bahwa peningkatan kadar air kulit dipengaruhi oleh kemampuan vitamin $\mathrm{E}$ dalam melindungi degradasi oksidatif terhadap kulit karena vitamin E berfungsi sebagai zat yang mempertahankan kelembapan kulit. Sedangkan menurut Tranggono, Iswari dan Latifah (2007), vitamin E sebagai pelembab yang dapat mempertahankan ikatan air di dalam kulit (Tranggono, 2007).

\section{Hasil Pengukuran Pori (Pore)}

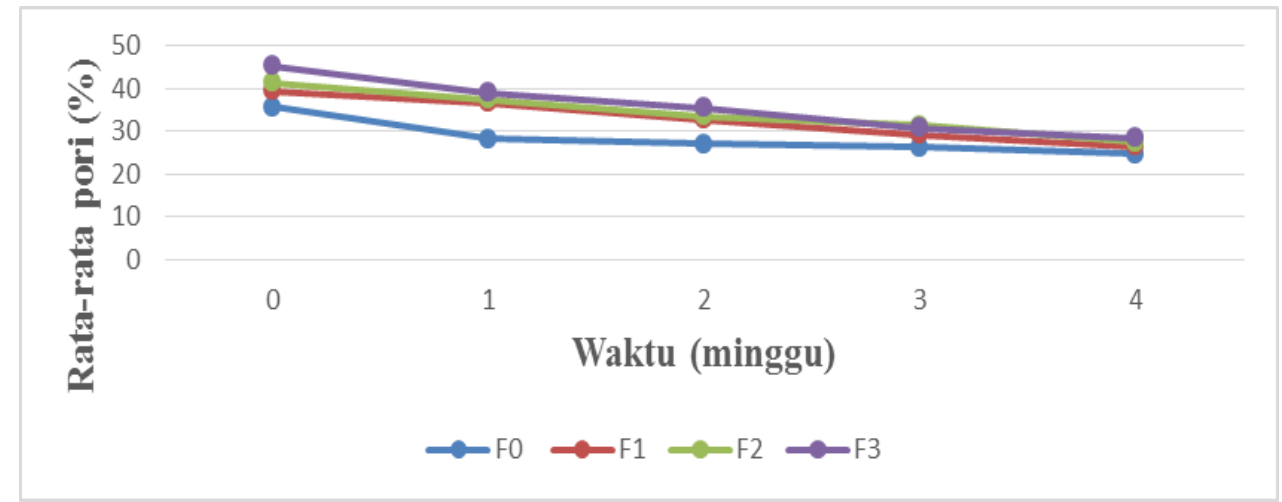

Gambar 3. Grafik hasil pengukuran pori (pore) selama 4 minggu

Hasil pengukuran pori menunjukkan bahwa pada formula Blemish Balm Cream Anti-aging terjadi perubahan kondisi pori kulit dari kondisi pori yang besar menjadi sedikit kecil setelah 4 minggu pemakaian sediaan Blemish Balm Cream. Hasil analisis statistik yang diperoleh menunjukkan adanya perbedaan yang signifikan $(\mathrm{p} \leq 0,05)$ antara formula setelah pemakaian sediaan Blemish Balm Cream tanpa vitamin E (blanko) dengan Formula yang mengandung vitamin E (F1, F2 Dan F3) selama pemakaian 4 minggu dengan adanya pengecilan ukuran pori pada wajah sukarelawan.

Persentase pengukuran pori yang diperoleh bahwa sukarelawan yang memakai sediaan Blemish Balm Cream tanpa mengandung Vitamin E (blanko) memiliki persentase perubahan pori yang lebih lama dibandingkan F1, F2 dan F3, dimana hasil rata-rata 
persentasi pori yang diperoleh sebelum pemakaian hingga setelah pemakaian 4 minggu adalah F0: 35,8-24,83\%., F1: 39,5-26,5\%., F2: 41,5-27,5\% dan F3:45,3-28,5\%. Batas persentase pori pada kulit wajah normal adala 0-19 (Aramo, 2012). Hasil pengukuran pori yang dihasilkan terlihat adanya perubahan kondisi pori kulit dari kondisi pori yang besar menjadi sedikit kecil setelah 4 minggu pemakaian sediaan Blemish Balm Cream. Hasil analisis statistik yang diperoleh menunjukkan adanya perbedaan yang signifikan $(\mathrm{p} \leq$ 0,05) antara formula setelah pemakaian sediaan Blemish Balm Cream tanpa vitamin E (blanko).

Menurut Dreyfuss (2015), salah satu faktor yang mempengaruhi pori-pori membesar adalah kulit yang sering terkena sinar matahari, perubahan suhu, faktor genetik, rusaknya kolagen, timbulnya jerawat dan kandungan air, penurunan elastisitas kulit, penumpukan sel kulit mati (kotoran). Persentase pengukuran pori yang diperoleh dimana hasil rata-rata persentasi pori sebelum pemakaian hingga setelah pemakaian 4 minggu adalah F0: 35,8-24,83\%., F1: 39,5-26,5\%., F2: 41,5-27,5\% dan F3:45,3-28,5\%. Batas persentase pori pada kulit wajah normal adala 0-19 (Aramo, 2012).

\section{Hasil Pengukuran Noda (Melanin)}

Uji pengukuran noda atau melanin pada kulit wajah dilakukan menggunakan perangkat skin analyzer dengan perbesaran lensa 60x (Aramo, 2012).

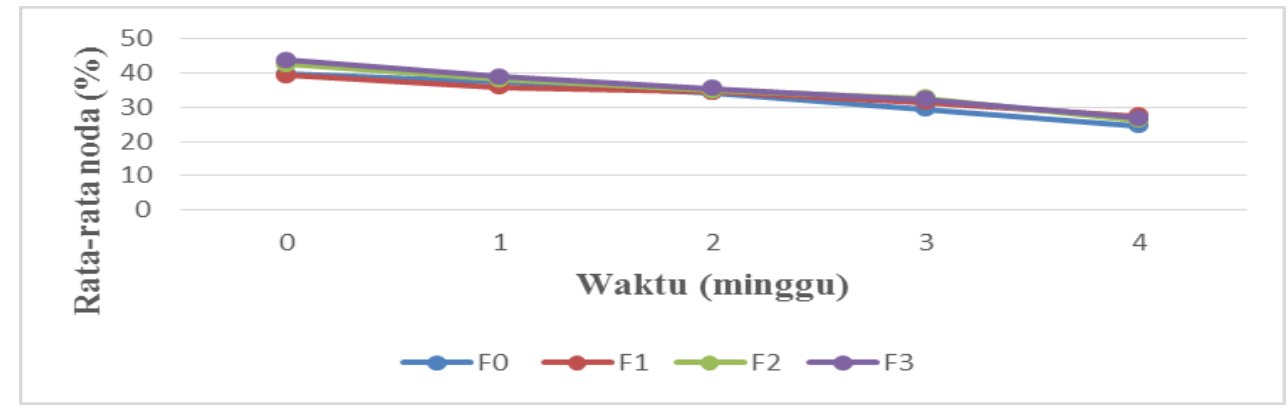

Gambar 4. Grafik hasil pengukuran noda atau melanin selama 4 minggu

Berdasarkan hasil pengukuran noda atau melanin, persentase pengukuran noda yang diperoleh dimana hasil rata-rata persentasi sebelum pemakaian hingga setelah pemakaian 4 minggu adalah F0: 39,83-29,5\%., F1: 39,33-27,3\%., F2: 42,5-26,1\% dan F3:43,8-38,7\%.

Hasil analisis statistik yang diperoleh terjadi adanya perbedaan nilai yang signifikan $(\mathrm{p} \leq 0,05)$ antara formula setelah pemakaian sediaan Blemish Balm Cream tanpa vitamin E (blanko) dengan Formula yang mengandung vitamin E (F1, F2 dan F3) selama pemakaian 4 minggu dengan adanya pengurangan noda pada wajah sukarelawan. Batas persentase noda pada kulit wajah normal adalah 0-39 (Aramo, 2012). Hasil data yang diperoleh dari pengukuran noda bahwa persentase perubahan noda yang terjadi pada kulit wajah sukarelawan masih dalam batas normal.

\section{Hasil pengukuran kerutan (wrinkle)}

Pengukuran banyaknya keriput pada kulit wajah sukarelawan dimulai dengan pengukuran dari kondisi awal sebelum memakai dan sesudah pemakaian sediaan Blemish Balm Cream. Hasil uji keriput (wrinkle) pada kulit wajah sukarelawan dapat dilihat pada Gambar 5. 
Pengukuran kerutan (wrinkle) pada kulit wajah sukarelawan

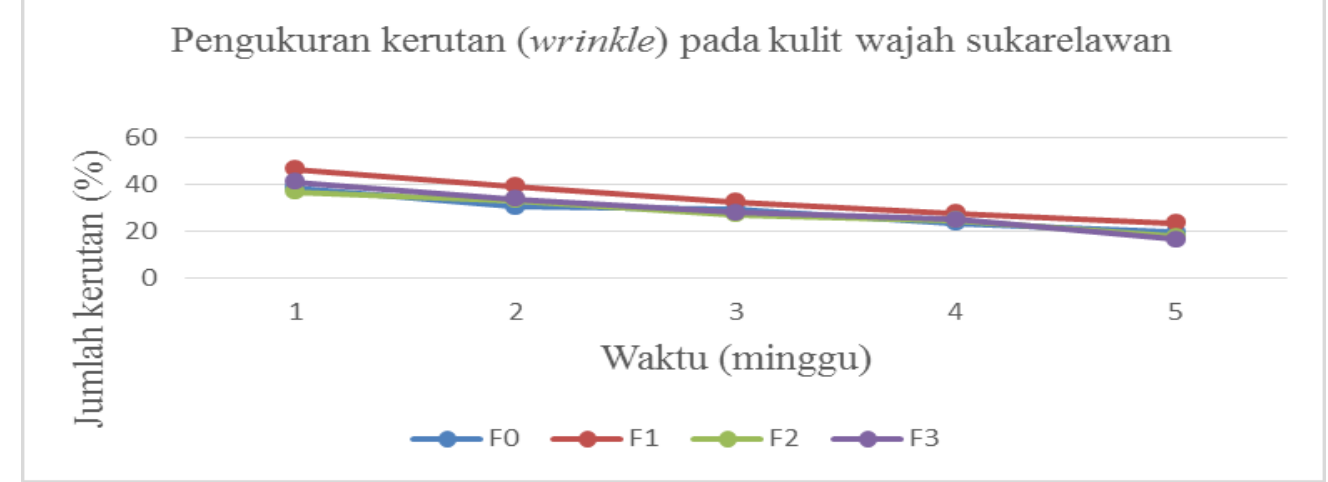

Gambar 5. Grafik hasil pengukuran keriput (Wrinkle) selama 4 minggu

Berdasarkan hasil pengukuran kerutan (wrinkle) kulit wajah persentase pengukuran keriput (wrinkle) yang diperoleh dimana hasil rata-rata persentasi keriput (wrinkle) yang diperoleh sebelum pemakaian hingga setelah pemakaian 4 minggu adalah F0: 38,5-19,5\%., F1: 46,3-23,3\%., F2: 36,6-17,8\% dan F3:40,8-16,5\%. hasil analisis yang diperoleh menunjukkan adanya perbedaan yang signifikan $(\mathrm{p} \leq 0,05)$ antara formula setelah pemakaian sediaan Blemish Balm Cream tanpa vitamin E (blanko) dengan formula yang mengandung vitamin $\mathrm{E}$ (F1, F2 dan F3) selama pemakaian 4 minggu dengan adanya pengurangan keriput pada wajah sukarelawan.

Batas persentase keriput kulit wajah normal adala 0-19 (Aramo, 2012). Hasil data yang diperoleh dari pengukuran keriput (wrinkle) bahwa Blemish Balm Cream F0, F1, F2 dan F3 memperoleh persentase pengurangan keriput dalam batas normal. Hasil analisis statistik yang diperoleh menunjukkan adanya perbedaan yang signifikan ( $\mathrm{p} \leq$ $0,05)$.

\section{KESIMPULAN}

Sediaan Blemish Balm Cream F0, F1, F2, dan F3 yang mengandung vitamin E, avobenzon dan oktil metoksisinamat tidak mempengaruhi stabilitas sediaan pada penyimpanan suhu kamar. Masing-masing formula tetap stabil selama penyimpanan. Aktivitas anti-aging sediaan Blemish Balm Cream berpengaruh terhadap penambahan vitamin E dengan konsentrasi yang berbeda, avobenzone dan oktil metoksisinamat, yang mengandung konsentrasi yang tinggi (vitamin E 5\%) memberikan efek aktivitas antiaging yang baik dan cepat.

\section{REFERENSI}

Afonso. S., Horita. K., Silva. J.P.S., Almeida. I.F., Amaral. M.H., Lobao, P.A., et al. (2014). Photodegradation of avobenzone Stabilization effect of antioxidants. Journal of Photochemistry and Photobiology B: Biology. Vol 140: 36-40.

Arakane, K. and Naru, E., (2016), Cosmeceuticals and Active Cosmetics, 3rd Ed., 281, CRC Press, NewYork. Halaman 75-78.

Aramo. (2012). Skin and Hair Diagnosis System. Sungnam Aram Huvis Korea Ltd. Halaman 1-10. 
Baki, G., and Alexander, K.S. (2015). Introduction to Cosmetic Formulation and Technology. New Jersey. Halaman 283, 292.

Barel, A.O., Paye M., and Maibach H.I. (2009). Handbook of Cosmetic Science and Technology Third Edition. New York: Taylor and Francis Group. Halaman 137141.

Ditjen POM. (1979). Farmakope Indonesia. Edisi Ketiga. Departemen Kesehatan RI. Jakarta. Halaman 8, 3, 649, 659.

Ditjen POM. (1985). Formularium Kosmetika Indonesia. Departemen Kesehatan RI. Jakarta. Halaman 22, 32, 36, 356.

Ditjen POM. (2014). Farmakope Indonesia. Edisi kelima. Jakarta. Departemen Kesehatan Republik Indonesia. Halaman 77-882.

FDA Monograph. (1999). FDA Sunscreen Monograph. Federal Register Vol 64: 27662769.

Garg, A., Anggarwal, D.,Garg,S., and Sigla,A.K. 2002. Spreading of Semisolid Formulation: AnUpdate.Pharmacheutical Tecnology: 84-105..

Lachman, L., Lieberman, H.A. and Kanig, J.L. (1994). The Theory and Practise of Industrial Pharmacy. Philadelphia: Varghese Publishing House. Halaman 10811083.

Mansur, M.C.P.P.R., Suzana, G.L., Cristal, C.C., Alane, B.V., Ronald, S.S., Octavio, A.F.P., et al. (2016). In Vitro and In Vivo Evaluation of Efficacy and Safety of Photoprotective Formulations Containing Antioxidant Extracts. Revista Brasileira de Farmacognosia. 26 (1) :251-258.

Mukul, S., Surabhi K., and Atul N. (2011). Cosmetical For Skin: An Overview. Asian Journal of Pharmaceutical and Clinical Research. Vol.4 : 974-2441.

Rege, S., Momin, S., and Bhowmick, D. (2014). Effect of Ascorbic Acid on the Oxidative Stability of Water-In-Oil Emulsion in the Presence of Lipophilic Antioxidants. Int. J. Food Prop. Vol 18: 259-265.

Reveny, J., Tanuwijaya, J., and Staenley, M. (2017). Formulation and Evaluating AntiAging Effect of Vitamin E in Biocellulose Sheet Mask. International Journal of PharmTech Research. Vol. 10(1): 320-330.

Tranggono, R.I., and Latifah, F. (2007). Buku Pegangan Ilmu Pengetahuan Kosmetik. Jakarta: PT. Gramedia Pustaka Utama. Halaman 3, 47, 58-59, 79, 81-83. 